\title{
“GELO NO PÊNIS, EXORCISMO E MEDO"*: GÊNERO, SEXUALIDADE E RELIGIÃO EM RELATOS DE SEMINARISTAS E PADRES HOMOSSEXUAIS
}

\author{
Eliane Rose Maio** \\ Jean Pablo Guimarães Rossi ${ }^{* * *}$
}

\section{RESUMO}

Este estudo está articulado a uma pesquisa de doutoramento, em andamento, e tem como objetivo principal discutir as questões de gênero, sexualidade e religião, que se atravessam nos relatos de padres e seminaristas homossexuais. Para tanto, tomamos como objeto de estudo os relatos presentes na reportagem publicada pela BBC News (British Broadcasting Corporation) em 2020, intitulada: "Gelo no pênis, exorcismo e medo: os padres gays silenciados pela Igreja no Brasil". Nos valemos do pressuposto foucaultiano de poder como perspectiva base, fundamental para compreensão de como as instituições - neste caso, instituições religiosas - funcionam como dispositivos de controle e docilização dos corpos e das sexualidades. As análises evidenciaram a presença de diversos mecanismos de disciplinamento, punição e contenção da (homo)sexualidade nas instituições religiosas.

Palavras-chave: Padres; Seminaristas; Homossexualidade; Religião; Relações de poder.

* A primeira parte do título do presente artigo foi extraída da primeira parte do título da matéria "Gelo no pênis, exorcismo e medo; os padres gays silenciados pela Igreja no Brasil", de Vitor Hugo Brandalise (2020).

** Pós-doutora e Doutora em Educação Escolar pela Universidade Estadual Paulista "Júlio de Mesquita Filho" (UNESP/ Araraquara). Graduada em Psicologia. Professora do Programa de Pós-graduação em Educação (Mestrado/Doutorado) junto à Universidade Estadual de Maringá (UEM). Coordenadora do Núcleo de Estudos e Pesquisas em Diversidade Sexual (NUDISEX/ CNPq). E-mail: elianerosemaio@yahoo.com.br

*** Doutorando pelo Programa de Pós-Graduação em Educação da Universidade Estadual de Maringá (PPE-UEM). Graduado em Psicologia. Integra o Núcleo de Estudos e Pesquisas em Diversidade Sexual (NUDISEX/CNPq) e o Grupo de Estudo e Pesquisa em Educação, Diversidade e Cultura (GEPEDIC/CNPq). Docente da Universidade Estadual do Paraná, UNESPAR/Campus de Campo Mourão. Bolsista CAPES. E-mail: psijeanpablo@gmail.com. 
"ICE ON THE PENIS, EXORCISM AND FEAR": GENDER, SEXUALITY AND RELIGION IN REPORTS OF SEMINARISTS AND HOMOSEXUAL PRIESTS

\section{ABSTRACT}

This study is about a Ph.D. research in progress, and its main objective is to discuss issues of gender, sexuality, and religion, which cross in the reports of priests and homosexual seminarians. For this purpose, our object of study is the reports present in the journalistic reporting published by BBC News (British Broadcasting Corporation) in 2020, entitled: "Ice on the penis, exorcism, and fear: the gay priests silenced by the Church in Brazil". Bearing this in mind, we make use of the Foucaultian assumption of power as a base perspective, fundamental to understand how institutions - in this case, religious institutions - function as devices for the control and socialization of bodies and sexualities. That said, the analyzes we explored showed the presence of different mechanisms of disciplining, punishing, and restraining (homo)sexuality in religious institutions.

Keywords: Priests; Seminarians; Homosexuality; Religion; Power relations.

\section{"HIELO EN EL PENE, EXORCISMO Y MIEDO": GÉNERO, SEXUALIDAD Y RELIGIÓN EN RELATOS DE SEMINARISTAS $Y$ PADRES HOMOSEXUALES}

\section{RESUMEN}

Este estudio está articulado a una investigación de Doctorado, en desarrollo, y tiene como objetivo principal discutir cuestiones de género, sexualidad y religión, que atraviesan los relatos de padres y seminaristas homosexuales. Para tal efecto, tomamos como objetivo de estudio tales relatos presentes en el reportaje publicado por la BBC News (British Broadcasting Corporation) en el 2020, titulada: "Hielo en el pene, exorcismo y miedo: los padres gays silenciados por la Iglesia en Brasil". Nos valemos del postulado focaultiano de poder como perspectiva base, fundamental para la comprensión de como las instituciones - en este caso, instituciones religiosas - funcionan como dispositivos de control y docilización de los cuerpos y de sexualidades. Los análisis evidenciaron la presencia de diversos mecanismos de disciplinamiento, punición y contención de (homo) 
sexualidad en las instituciones religiosas.

Palabras-clave: Padres; Seminaristas; Homosexualidad; Religión; Relaciones de poder.

\section{INTRODUÇÃO}

Este estudo está articulado a uma pesquisa de doutorado em andamento, iniciada em 2020, vinculada ao Programa de Pós-Graduação em Educação da Universidade Estadual de Maringá (PPE - UEM) e ao Núcleo de Estudos e Pesquisas em Diversidade Sexual (NUDISEX). Neste recorte preliminar, tomamos como objeto de estudo uma reportagem realizada pela BBC News (núcleo jornalístico da $\mathrm{BBC}$ ) publicada em março de 2020, intitulada: "Gelo no pênis, exorcismo e medo: os padres gays silenciados pela Igreja no Brasil” (Vitor Hugo BRANDALISE, 2020). A partir da referida reportagem, temos por intuito discutir os mecanismos de disciplinamento de gênero e da sexualidade que atravessam os relatos dos entrevistados por esta reportagem. Trata-se também de uma aproximação das/os autoras/es com o objeto de estudo em questão e uma amostra do que realizamos durante a investigação de doutoramento (2020-2023).

Tomamos emprestado o seguinte questionamento de Guacira Lopes Louro (2008, p. 18): "Que instâncias e espaços sociais têm o poder de decidir e inscrever em nossos corpos as marcas e as normas que devem ser seguidas?". Respondendo ao questionamento da autora, compreendemos que o espaço religioso e, de modo mais específico, o espaço de formação sacerdotal, configura-se como uma das instituições atravessadas por pedagogias que atuam, educam os corpos, o gênero e a sexualidade de seus integrantes.

Dentre as pesquisas localizadas, que abordam questões de gênero e homossexualidade entre os seminaristas, encontramos a dissertação de mestrado de Arlindo José de Souza Neto, intitulada "'O bem maior que posso ter'”: uma análise antropológica sobre a vocação sacerdotal católica no Brasil, defendida no ano de 2015. Apesar do objetivo do autor não estar propriamente relacionado à questões de gênero e sexualidade, mas sim uma investigação etnográfica em torno dos mecanismos de ação que influem na escolha da vida sacerdotal, ainda assim, notamos que o autor suscita, em observação realizada durante 
uma nota de rodapé, a percepção que obteve durante a realização da etnografia, de que é pertinente uma pesquisa se debruçar sobre a sexualidade dos seminaristas e que, até então, só existiriam menções acerca de uma possível "subcultura homossexual", mas nenhum estudo sobre:

[...] nas entrevistas e questionários não obtive dados que apontem a existência de seminaristas homossexuais atualmente no Seminário. Mas um estudo que se debruce primariamente sobre sexualidade e religiosidade entre seminaristas católicos, mostra-se muito pertinente. De qualquer forma, quero destacar uma nota de página encontrada na literatura que indica uma possível existência de uma subcultura homossexual, embora não exista nenhum estudo sobre, apenas menções [...] Ainda não podemos analisar até que ponto a sexualidade, ou melhor, a homossexualidade, interfere na formação e na construção de uma identidade católica entre os seminaristas. É difícil avaliar essa questão, uma vez que essa "subcultura" é sigilosa e o tema é um tabu, o que impede a coleta sistemática de dados (Arlindo José de Souza NETO, 2015, p. 80).

De fato, uma das afirmativas feitas pelo autor supracitado e com a qual coadunamos, refere-se ao quanto o tema da homossexualidade no clero, ainda é permeado pelos tabus da igreja, avigorando como "é raro conseguir autorização do clero para estudar a vida institucional [dentro] do seminário" (Silvio José BENELLI, 2009, p. 168). De todo modo, a homossexualidade em meio a vida sacerdotal é uma questão que sempre existiu em meio ao clero, mas que tem obtido maior visibilidade pela Igreja e pelas pesquisas acadêmicas, principalmente nos últimos anos. Frente a esta consideração, compreendemos que esta pesquisa, em conjunto com outras iniciativas recentes, como a própria reportagem em questão (Vitor Hugo BRANDALISE, 2020), vai ao encontro da necessidade de elucidar as questões que tangem a (homo) sexualidade dos sacerdotes, ao mesmo tempo em que pode cooperar para o avanço dos debates em torno da vida sexual de seus candidatos e que tem gerado tanta agitação nos dias atuais.

Este artigo foi organizado em duas seções com algumas subseções, sendo a primeira seção intitulada: "Gênero, Sexualidade, Religião: uma abordagem histórica", na qual discutimos como o controle da sexualida- 
de está historicamente atrelado ao poder religioso da instituição católica. Em seguida, na subseção "Igreja, seminário e homossexualidade", nos atemos a elucidar brevemente sobre como as questões referentes à homossexualidade dos candidatos ao sacerdócio têm sido abordadas pela instituição católica.

Na segunda seção, intitulada: “'Os padres gays silenciados pela Igreja no Brasil': a reportagem da BBC News" (Vitor Hugo BRANDALISE, 2020), explanamos a reportagem realizada pela BBC e expomos as análises subsequentemente na subseção intitulada: " 0 único pecado era a sexualidade': culpa, (auto) punição e confissão". Nesta seção, selecionamos alguns excertos da reportagem, articulando com as análises. Dentre alguns dos pressupostos teóricos, nos ancoramos, sobretudo, nos estudos de Michel Foucault $(1985,1988,2010,2014)$; Nathan Melo da Costa (2017); Sílvio José Benelli (2006) e Robert Daibert Jr. (2013). Faz-se pertinente justificar que a análise que empreendemos neste artigo, trata-se apenas de um recorte, que parte dos relatos que nos são oferecidos pela reportagem, nosso objeto de estudo. Portanto, admitimos a possibilidade de que também existam padres e seminaristas homossexuais com vivências importantes e relatos diferentes dos que se encontram na reportagem.

\section{GÊNERO, SEXUALIDADE, RELIGIÃO: UMA ABORDAGEM HISTÓRICA}

Nosso intuito com esta seção é discutir de que modo o poder religioso da instituição católica, historicamente, atuou e atua como pedagogias de disciplinamento do gênero e da sexualidade. Para tanto, de antemão, nos apoiamos na compreensão de Guacira Lopes Louro, de que os conceitos de gênero não são naturais, mas constructos que se produzem por meio da articulação de "inúmeras aprendizagens e práticas, insinua-se nas mais distintas situações, é empreendido de modo explícito ou dissimulado por um conjunto inesgotável de instâncias sociais e culturais. É um processo minucioso, sutil, sempre inacabado" (2008, p. 18).

Deste modo, se os corpos se constroem em meio à articulação de aprendizados em diversas instâncias sociais (Fabiane Freire FRAN- 
ÇA, 2014; Guacira Lopes LOURO, 2008), há que se considerar que na educação do(s) gênero(s) e da(s) sexualidades, o elemento religioso é um dos aspectos históricos basilares que contribui para a "existência de um conjunto de atributos que tentam conter, ajustar, disciplinar e punir os sujeitos para que se adequem àquilo que a sociedade avalia como 'normal'” (João Paulo BALISCEI, 2020, p. 24).

Como lembra Mary Neide Figueiró sobre a história da sexualidade, "sua compreensão tem feito ver que ela tem sido reprimida e controlada, ao longo dos séculos, pela Igreja, pela Medicina, pelo Estado, pela Escola e também pela família" (2014, p. 54). Com relação à instituição religiosa, a partir de um resgaste histórico, compreendemos que a Alta Idade Média ${ }^{1}$ presenciou a aceleração do disciplinamento sexual, motivada principalmente em função da expansão do poder da Igreja ocidental, tanto em domínio social, quanto intelectual. Em toda a Europa, as leis eclesiásticas em torno do sexo e do casamento, foram elaboradas e ainda mais endurecidas, tanto para os clérigos, quanto para laicos/as, reis e camponeses/as. Um exemplo do endurecimento destas normas foi o início da campanha para sancionar a obrigatoriedade do celibato para todos os sacerdotes e a proibição do casamento de qualquer membro do clero (Faramerz DABHOIWALA, 2013; Michel FOUCAULT, 1988; André Sidnei MUSSKOPF, 2008; Alessandra dos Reis de SOUZA, 2020).

Além disso, as penalidades civis direcionadas à população, por conta das chamadas infrações sexuais, tomavam contornos mais rígidos, principalmente em função da criação dos tribunais eclesiásticos. Exemplo disto, é que no final do século XIII esses casos somavam de $60 \%$ a $90 \%$ dos litígios, em grande parte relacionados aos julgamentos por prostituição, adultério ou fornicação (Faramerz DABHOIWALA, 2013). Quanto às penalizações por estas condutas, eram das mais variadas como:

A Idade Média costuma ser dividida pela historiografia em dois períodos: a Alta Idade Média (Séc. V a X), que se caracteriza pela dissolução da sociedade antiga e a formação do sistema feudal; a Baixa Idade Média (séc. XI a XV) que representa o declínio do sistema feudal e a formação do sistema capitalista (Antônio Roberto XAVIER; Eduardo Ferreira CHAGAS; Edilberto Cavalcante REIS, 2017). 
Ser surrado em público repetidas vezes perto da igreja da paróquia e do mercado, aos olhos de toda a comunidade [...]. Em Londres, Bristol e Gloucester, eles construíram uma "gaiola” pública especial no mercado principal, onde prendiam e expunham prostitutas, adúlteras e padres libidinosos: em outros lugares, cucking-stools ${ }^{2}$ eram usados para punir prostitutas [...] Também se instauraram elaborados rituais de punição cívica para prostitutas, cafetinas e adúlteros. Infratores graves eram conduzidos numa longa procissão pública pela cidade, vestindo trajes simbolicamente degradantes, e acompanhados por um estardalhaço de panelas e bacias. Às vezes, eles também eram açoitados, colocados no pelourinho, tinham os cabelos raspados ou eram banidos da cidade (Faramerz DABHOIWALA, 2013, p. 28).

Mesmo com a severidade das penalizações, a frequência com que elas continuavam ocorrendo indicavam que o sexo "ilícito" acontecia com constância progressiva. Um dos comportamentos mais corriqueiros era a coabitação (vida compartilhada, com ou sem casamento, incluindo relacionamentos sexuais), tanto no clero quanto entre os laicos, e perdurou até a Reforma Protestante. A criminalização da fornicação era ainda mais dificultada pela Lei Matrimonial da própria Igreja, pois até então, o que era exigido para formação de um laço matrimonial, era que um homem e uma mulher trocassem votos, ou seja, bastava o "consentimento do próprio casal, sem a necessidade de nenhum padre, testemunhas ou cerimônias" (Faramerz DABHOIWALA, 2013, p. 29).

Dentre alguns dos marcos históricos da instituição católica, apresentamos que o Concílio de Trento $^{3}$ (1545-1563), o mais longo da história da Igreja, realizado em 1545, foi um dos impulsionadores no endurecimento das normativas para regulação da identidade católica e, sobretudo, na consolidação do celibato e do confessionário como dispositivo para exame de si, sobre o próprio corpo e o prazer. No entanto, é pertinente frisar que concílios anteriores já apresentavam alguns indicativos em torno da relevância atribuída ao celibato clerical

\footnotetext{
2 "Cadeira em que o[a] infrator[a] era amarrado[a] e humilhado[a] publicamente, ou mergulhado[a] na água” (Faramerz DABHOIWALA, 2013, p. 28).

3 Concílios são reuniões de dignitários eclesiásticos, bispos, presidida ou sancionada pelo papa, para deliberar sobre questões de fé, costumes, doutrina ou disciplina eclesiástica (ARQUIDIOCESE DE CAMPINAS, 2017).
} 
e das legislações sobre o controle sexual, como os Concílios de Arles (314) e Elvira (306), que se preocuparam em delimitar fronteiras entre cristãos/ãs e não cristãos/ãs. Os cânones redigidos por estes concílios evidenciaram a importância à renúncia sexual e, paralelamente, o controle sobre o corpo e a sexualidade (Macário Lopes de CARVALHO JÚNIOR, 2013). Exemplo disto é mencionado na pesquisa de mestrado de Macário Lopes de Carvalho Júnior, que afirma que os legisladores de Elvira "colocaram a condicionante de que a pessoa que desejava tornar-se cristã deveria ter uma conduta honrada e correta, para que não se dispensasse a graça da salvação indiscriminadamente" (2010, p. 139). Dito isto, boa parte das normativas centravam-se na regulação das relações matrimoniais a partir de sucessivas interdições ao casamento entre pessoas cristãs e não cristãs, ou sobre aqueles/as que se encontravam em estado de "impureza".

O autor (Macário Lopes de CARVALHO JÚNIOR, 2010) ainda justifica que o Cristianismo neste período se caracterizava como um sistema em processo de formação, em que as crenças e práticas pouco estavam normatizadas, fazendo com que as regulações oriundas da atividade conciliar se apresentassem de forma tão intensa. Todavia, Claudomilson Fernandes Braga (2007) explana que, apesar do Concílio de Elvira ter criado decretos já desfavoráveis ao casamento do clero, tal regulamentação não obteve grande extensão, houve pouca adesão e não apresentou grandes esforços para que fosse colocada em vigor. Para Faramerz Dabhoiwala,uma coisa era fato: "a tendência principal ao longo do tempo era de controle e punição, sempre mais rígidos, do sexo não conjugal, tanto pelas autoridades seculares quanto pelas eclesiásticas" (2013, p. 30).

Quanto à Igreja Oriental sua legislação, desde o séc. V, já frisava a necessidade da disciplina celibatária por parte do clero, estabelecida pelo Concílio de Trulano (692). Neste sentido, somente os clérigos celibatários poderiam ser consagrados como bispos e não poderiam aderir ao matrimônio após a ordenação, "o que sugere, até certo ponto, o princípio do sacerdócio celibatário também se aplica à Igreja do oriente" (Claudomilson Fernandes BRAGA, 2007, p. 56). Ainda sobre o celibato pastoral em igrejas orientais Dag Oistein Endjso acrescenta que: 
O princípio do celibato pastoral jamais se enraizou em igrejas orientais, muito embora bispos devam ser celibatários. Caso um padre casado seja ordenado bispo, tradicionalmente sua esposa é mandada a um convento [...] A ideia de padres abstinentes teve, de início, maior aceitação no ocidente. Uma das primeiras tentativas formais de impor o celibato aos padres ocorreu por iniciativa de um bispo espanhol no ano 325, durante o primeiro concílio de Niceia, mas foi imediatamente derrotada devido à oposição do oriente. É interessante notar que o conceito de padres abstinentes nem sempre implicava que fossem solteiros, mas que "guardassem distância de suas esposas" (2014, p. 48).

Foi somente com o primeiro Concílio de Latrão, em 1123, que se invalidou o casamento daqueles que ocupavam ordens sacras, fazendo com que sacerdotes que viessem a se casar se tornassem impedidos de exercerem suas funções na Igreja e os homens já casados, que aspiravam ao sacerdócio, tivessem que abandonar suas esposas. Porém, na prática, a defesa católica do celibato geralmente significava a abstinência do casamento e não da prática sexual (Claudomilson Fernandes BRAGA, 2007; Dag Oistein ENDSJO, 2014). Como é ressaltado por Nathan Melo da Costa, paulatinamente "a Igreja Católica vai se interessando sobre a sexualidade dos sujeitos e a pastoral católica vai, cada vez mais, a partir do século XVI, lançando seus braços controladores sobre a sexualidade alheia, medindo-o (sic), lhe atribuindo juízo moral e formas pré-estabelecidas" (2017, p. 64). Tal ideia se coaduna com o que Michel Foucault (1988), em sua obra "A vontade do saber", identifica como o que denomina de "dispositivo de aliança", que se caracteriza por,

Um sistema de regras que define o permitido e o proibido, o prescrito e o ilícito; o dispositivo de sexualidade funciona de acordo com técnicas móveis, polimorfas e conjunturais de poder. O dispositivo de aliança conta, entre seus objetivos principais, o de reproduzir a trama de relações e manter a lei que as rege; o dispositivo de sexualidade engendra, em troca, uma extensão permanente dos domínios e das formas de controle. Para o primeiro, o que é pertinente é o vínculo entre parceiros com status definido; para o segundo, são as sensações do corpo, a qualidade dos prazeres, a natureza das impressões, por tênues ou imperceptíveis que sejam (Michel FOUCAULT, 1988, p. 101). 
Michel Foucault acrescenta ainda que os dispositivos de aliança servem como propósito de reger os corpos e as sexualidades, perseverar as mesmas relações de poder e, assim, "proliferar, inovar, anexar, inventar, penetrar nos corpos de maneira cada vez mais detalhada e controlar as populações de modo cada vez mais global" (1988, p. 100). Tal exercício de controle pode ser visualizado a partir da mudança, ocorrida com o Concílio de Trento, a respeito das noções de pecado, castidade e confissão. Se, em tempos anteriores, a ideia de pecado contra a castidade estava relacionada com quem e de que forma o corpo se relacionava, agora o corpo por si só, é o centro da questão “[...] é o corpo e suas sensações e desejos, são os movimentos da concupiscência [...]. 0 pecado do sexo não está mais ligado à legitimidade das relações e uniões entre as pessoas, agora está localizada sobre o próprio corpo" (Nathan Melo da COSTA, 2017, p. 65).

Foi o Concílio de Trento (1545) que asseverou a obrigatoriedade do celibato, que já vinha sendo discutida em concílios anteriores, tanto para os clérigos, quanto para os candidatos ao sacerdócio e seminaristas. Ainda ressaltamos que este concílio "não decretou nenhuma lei nova sobre o celibato, apenas confirmou o que está em vigor até os dias de hoje" (Claudomilson Fernandes BRAGA, 2007, p. 57). Dentre os mecanismos disciplinares que foram essenciais para o controle da sexualidade, um deles se refere à necessidade de confissão e análise de consciência, motivada pelo compromisso de penitência, sendo que aqueles que têm a devida chancela para acolher e ditar os discursos que funcionam como verdadeiros, são figuras como: padre, bispo e diretor (Nathan Melo da COSTA, 2017). Trata-se de "falar tudo ou o máximo possível sobre a vida e o vivido; e pela exclusividade, falar sobre si somente para os autorizados e qualificados" (Nathan Melo da COSTA, 2017, p. 68). Assim, a confissão torna-se um mecanismo de controle que produz os modos de ser mais desejáveis, evidenciando as relações de poder e os níveis de sujeição ao qual o sujeito está submetido.

Neste contexto, a consolidação do celibato eclesiástico pelo Concílio de Trento, tornou-se pressuposto essencial para a seleção de candidatos e formação de seu clero, ao mesmo tempo em que homens casados foram concomitantemente perdendo espaço na hierarquia 
católica (Nathan Melo da COSTA, 2017; Robert DAIBERT JR; 2013). Entretanto, Claudomilson Fernandes Braga ressalva que "a obrigação solene do celibato, que se iniciou pelo Concílio Ecumênico de Trento (1545), é ratificada em definitivo pelo Concílio Ecumênico Vaticano II, é, por fim, inserida no Código de Direito Canônico" (2007, p. 55).

Robert Daibert Jr. em seu texto "Entre homens e anjos: padres e celibato no período colonial no Brasil”, explica que a elevação moral deveria ser a marca distintiva destes homens, principalmente no que tange ao controle dos desejos sexuais, da "continência, castidade, disciplina e perfeição no serviço a Deus. Vida de anjos" (2013, p. 56). Nas palavras do autor,

[...] a abstinência sexual afirmou-se como sinal de superioridade espiritual dos clérigos sobre os leigos. O celibato se tornou assim a marca identitária de um grupo de homens que se distinguiam dos demais por seu estado de pureza, status que lhes permitia inclusive dirigir espiritualmente aqueles que não se enquadravam nessa condição (Robert DAIBERT JR, 2013, p. 52).

A Igreja conferiu um olhar de antagonismo entre o sexo e o sagrado, ao entender que a divinização da vida assexuada atribui ao sacerdote o caráter de autoridade moral, símbolo de entrega à vida religiosa (Nathan Melo da COSTA, 2017). Robert Daibert Jr. (2013), ainda reforça que o Concílio de Trento foi realizado em meio às dificuldades para afirmação do celibato, pois muitos padres casavam-se em segredo antes e até mesmo depois da ordenação. Uma das saídas encontradas pela Igreja foi a elevação do casamento à condição de sacramento, tornando-o uma cerimônia pública, formal, na presença de uma autoridade religiosa e ademais testemunhas, tendo como um dos principais fins, "tentar impedir que homens casados em segredo se tornassem padres" (Robert DAIBERT JR, 2013, p. 61). Entretanto, a severidade dos preceitos clericais não foi suficiente. Exemplo nesse sentido são os relatos de diversos viajantes e cronistas, que expuseram as aventuras amorosas e sexuais vivenciadas pelos "homens de Deus": 
Ficavam mais conhecidos pelo nome de suas amantes do que por seus próprios nomes. Um era o padre de Fulana, o outro de Beltrana. O nome de suas prostitutas é que demarcava suas identidades. Os conventos e seminários eram inclusive lugar de descanso para essas trabalhadoras noturnas. No confessionário, esses padres aproveitavam para assediar as mulheres ao invés de lhes inspirar sentimentos de piedade. À noite, alguns se disfarçavam de escravos e saíam armados com facas em busca de aventuras amorosas. Outros se vestiam de mulheres em busca de prazeres, percorrendo as ruas da cidade pelas madrugadas (Robert DAIBERT JR., 2013, p. 53).

Se por um lado durante o Brasil Colônia havia padres que construíam famílias, tornavam-se pais, sustentando relacionamentos duradouros e estáveis que perduravam toda a vida, por outro lado existiam sacerdotes libertinos que se relacionavam de maneira instável com muitas mulheres, homens, crianças e adultos/as. Assim, buscavam modos de lidar com a questão do celibato, "construindo diferentes alternativas para saciar seus desejos sexuais ou caminhos para reprimi-los" (Robert DAIBERT JR., 2013, p. 54). Exemplo disto são os trabalhos de Luiz Mott (2006), que explanam um dos mecanismos mais veementes na perseguição dos/a considerados/as "sodomitas" - "em referência ao pecado de Sodoma que resultou no castigo divino destruidor (Gn 19)" (Luís Corrêa LIMA, 2017, p. 8) - que aconteceu por meio do Tribunal do Santo Ofício da Inquisição (1535-1821) e atuou na prisão, sequestro de bens e queima dos "mais escandalosos e 'incorrigíveis'" (Luiz MOTT, 2006, p. 5). Neste processo, além dos/as indígenas ${ }^{4}$ que foram mortos/as, muitos padres e religiosos/as homossexuais, também foram denunciados/as e condenados/as. Diversas destas condenações são descritas no trabalho de Luiz Mott, como as duas relatadas a seguir, ocorridas entre os anos de 1646 e 1669:

1646: Padre Antonio de Souza, morador em Salvador, é acusado pelo escravo Domingos Bango, angola que "carregando na rede ao

4 O primeiro relato de morte por homofobia no Brasil é datado de 1614, pelo padre capuchinho francês Yves D’Evreux (1874), contra um indígena Tibira Tupinambá do Maranhão, estraçalhado por um canhão da Igreja. Homens, homossexuais, era conhecidos como "tibiras" e as mulheres lésbicas eram conhecidas como "çacoaimbeguira" (Luiz MOTT, 2006). 
Padre, este mandou que entrasse em sua casa e de portas fechadas, ordenou que mostrasse-lhe as vergonhas enquanto punha órgão desonesto na mão do negro, o qual após receber um beijo, disse-lhe que o sacerdote não era clérigo mas o diabo", fugindo espantado. 1669: "há fama pública e constante entre a plebe, clérigos, religiosos e nobreza da Bahia que o Padre José Pinto de Freitas exercita o abominável pecado nefando com homens, estudantes e rapazes, pegando-Ihes pela braguilha, abraçando-os e beijando-os, acometendo-os com dinheiro, ouro e joias, por ser rico e poderoso" (2006, p. 3).

Segundo Robert Daibert Jr. (2013, p. 74), "muitos padres acabavam ensinando o pecado, em vez de combatê-lo". No Brasil, durante o período colonial, era frequente o envolvimento sexual entre os clérigos, já que a convivência dentro dos seminários, mosteiros e outros locais, viabilizava que compartilhassem, em sigilo, de carências afetivas e de seus desejos sexuais. Fora do ambiente religioso, os parceiros sexuais destes padres eram, de forma geral, homens escravizados, meninos, homens empobrecidos e estudantes. Além disso, a chamada "sodomia" era um delito passível de julgamento pelo Tribunal do Santo Ofício, submetido a penas rigorosas, como a morte na fogueira. Tal fato agravava-se ainda mais caso houvesse a constatação de que se tratava de "sodomia perfeita", ou seja, o ato sexual entre homens, com penetração anal e a emissão de sêmen. Da mesma maneira que, concomitantemente, havia clérigos que se esforçavam "para fugir das molícies, da sodomia, do adultério e do amancebamento. Tentavam ser anjos" (Roberto DAIBERT JR., 2013, p. 78).

Dag Oistein Endsjo (2014) afirma que em vários países católicos, até meados do século XX, era comum que padres vivessem junto às suas concubinas, eram também conhecidos pelas prostitutas, como bem é identificado no ano de 1414, quando cerca de setecentas prostitutas estiveram presentes pela cidade, durante a realização do Concílio de Constança. Apesar da exigência formal do celibato de seus padres, a Igreja católica reconhece que existe uma parcela de sacerdotes que tem, de fato, vida conjugal (Dag Oinstein ENDSJO, 2014). Da mesma maneira que também tem reconhecido que existem candidatos e sacerdotes homossexuais. Sobre tal afirmação, para Luís Correa Lima (2017), ainda que a estatística de rapazes homossexuais seja imprecisa, uma 
coisa é nítida; rapazes homossexuais estão presentes nos seminários e é preciso encarar as múltiplas formas com que grupos vocacionais, seminários, paróquias e ademais comunidades católicas, lidam com estes sujeitos. De acordo com o autor, por vezes, a sexualidade é tratada apenas em momentos pontuais, quando mencionam outros assuntos "considerados mais importantes, como o celibato e a castidade. Outras vezes fala-se da sexualidade apenas de modo negativo, como se ela fosse em si mesma uma realidade perigosa e pecaminosa [...]" (Luís Correa LIMA, 2017, p. 5).

$\mathrm{Na}$ atualidade, ainda que a Igreja católica tenha afrouxado o rigorismo excludente e homofóbico, historicamente arquitetado, as "diretrizes das autoridades eclesiásticas no tocante à homossexualidade demonstram certa insegurança e ambivalência" (Edênio VALLE, 2014, p. 26) como observamos em alguns dos documentos produzidos pela instituição nos últimos anos, que visam orientar os seminários no acolhimento de jovens homossexuais para a vida sacerdotal. Como é destacado por Edênio Valle (2014), atualmente persistem dificuldades para que a Igreja católica consiga dialogar com a diversidade no campo da sexualidade, oriunda no "fato de o magistério eclesiástico continuar mantendo uma visão e um referencial unilateralmente heterossexual, forjados por séculos de tradição patriarcal" (Edênio VALLE, 2014, p. 27). No próximo tópico objetivamos discutir como as questões da homossexualidade entre seminaristas têm sido abordadas pela Igreja.

\subsection{Igreja, seminário e homossexualidade}

Para iniciar a discussão neste tópico, destacamos duas pesquisas, sendo a primeira delas, com respeito à investigação empreendida por Frederic Martel (2019), que em seu livro "No armário do Vaticano: poder, hipocrisia e homossexualidade" expõe o seu trabalho entrevistando durante quatro anos, centenas de cardeais e ex-cardeais homossexuais, coletando seus relatos e suas histórias, evidenciando o funcionamento do que nomina como "código do armário", que consiste no seguinte pressuposto: 
[...] tolerar a homossexualidade dos padres e dos bispos, desfrutar dela, se for o caso, mas mantê-la em segredo sob quaisquer circunstâncias. A tolerância anda de mãos dadas com a discrição [...]. Como viria a descobrir no decurso desta longa investigação, ser gay, no clero, consiste em fazer parte de uma espécie de norma (Frederic MARTEL, 2019, p. 21).

Semelhante às considerações de Martel (2019), na pesquisa de Mestrado realizada por Nathan Melo Costa (2017), intitulada "Religião e sexualidade: um estudo da vida celibatária dos seminaristas no Rio de Janeiro", o autor realizou entrevistas com quatro jovens ex-seminaristas, aproveitando-se do método de História de Vida. Nathan Melo da Costa (2017) também chega à conclusão de que a vida dos candidatos ao sacerdócio é permeada por experiências sexuais homoafetivas, ainda que o celibato seja imposto como condição obrigatória para a vida religiosa, e,

Tendo em vista os resultados que essa pesquisa alcançou foi percebido que a vida celibatária daqueles que colaboraram com essa pesquisa é marcada pela iniciação amorosa e sexual, por inúmeras experiências sexuais durante o período de formação, por experiências homoafetivas e que na prática a fidelidade ao celibato não está vinculada necessariamente à continência total do sexo (Nathan Melo da COSTA, 2017, p. 7).

Ambos os autores (Nathan Melo da COSTA, 2017; Frederic MARTEL, 2019) evidenciam a urgência em problematizar as questões acerca da (homo) sexualidade dos candidatos à vida sacerdotal, uma vez que nos últimos anos aumentaram as discussões sobre como lidar com os padres homossexuais dentro da Igreja. Exemplo disto é o fato de que "em 2013, respondendo a uma pergunta sobre a influência de sacerdotes gays no Vaticano, o Papa Francisco disse sua famosa frase "Quem sou eu para julgar?" (Vitor Hugo BRANDALISE, 2020, s/p).

Segundo Marcos Matos (2020), em seu livro "Discurso religioso e heteronormatividade: uma análise da liturgia nupcial da Igreja Católica", um marco dentro da Igreja e que significou o impulso para tais debates, foi o Concílio Vaticano II (1962-1965). Este Concílio representou a intensificação do discurso heteronormativo, haja vista a oposição frontal 
às mudanças advindas da expressividade dos movimentos feministas e LGBTI+ (Lésbicas, Gays, Bissexuais, Transexuais, Intersexuais, outras possibilidades), que começavam a ganhar força, em meados da metade do século XX e militavam por "visibilidade, liberdade, igualdade e reconhecimento das identidades de gêneros, das relações de amor e das famílias constituídas para além do padrão heteronormativo" (Marcos MATOS, 2020, p. 126). Desse modo, este concílio representou, concomitantemente, um complexo processo de renovações eclesiásticas e uma postura reacionária aos avanços exteriores a ela, recrudescendo as críticas à homossexualidade, reafirmando a "exclusividade da relação conjugal entre homem e mulher e atuando com protagonismo no combate político e jurídico à liberalização sexual e à legitimação de relações não-heterossexuais ou não-monogâmicas" (Marcos MATOS, 2020, p. 126).

Marcos Matos (2020) salienta que, desde então, algumas fontes documentais foram produzidas no sentido de dispor o seu olhar sobre a sexualidade dos candidatos ao seminário. Dentre estes documentos, um deles, que aborda de forma mais enfática o tema em questão, denomina-se: "Instrução sobre os Critérios de Discernimento Vocacional acerca das Pessoas com Tendências ${ }^{5}$ Homossexuais e da sua Admissão ao Seminário e às Ordens Sacras" (2005). Sobre a seleção de candidatos, expõe-se:

[...] a Igreja, embora respeitando profundamente as pessoas em questão, [9] não pode admitir ao Seminário e às Ordens sacras aqueles que praticam a homossexualidade, apresentam tendências homossexuais profundamente radicadas ou apoiam a chamada cultura gay. [10]. Estas pessoas encontram-se, de facto, numa situação que obstaculiza gravemente um correcto relacionamento com homens e mulheres. De modo algum, se hão-de transcurar as consequências negativas que podem derivar da Ordenação de pessoas com tendências homossexuais profundamente radicadas (CONGREGAÇÃO PARA A EDUCAÇÃO CATÓLICA, 2005, s/p, grifo nosso).

0 documento ainda especifica que cabe ao diretor espiritual a função de ajudar os candidatos a discernirem se realmente possuem

\footnotetext{
Repudiamos o termo "tendência homossexual", por compreendermos que há uma série de preconceitos por trás desta expressão, uma vez que pode indicar o entendimento de um suposto desvio e anormalidade comportamental, além de pressupor um reducionismo entre gênero e sexualidade.
} 
as exigências necessárias para o sacerdócio, além de avaliar se o jovem apresenta "todas as qualidades da personalidade e assegurar-se de que o candidato não apresente distúrbios sexuais incompatíveis com o sacerdócio" (CONGREGAÇÃO PARA A EDUCAÇÃO CATÓLICA, 2005, s/p, grifos nossos). Além disso, "se um candidato pratica a homossexualidade ou apresenta tendências homossexuais profundamente radicadas, o seu director espiritual, bem como o seu confessor, têm o dever, em consciência, de dissuadi-lo de prosseguir para a Ordenação" (CONGREGAÇÃO PARA A EDUCAÇÃO CATÓLICA, 2005, s/p, grifos nossos).

Edênio Valle (2014), também expõe alguns documentos que marcam algumas posições que tangem a abordagem da homossexualidade por parte de Igreja, dentre eles, citamos os seguintes: "Declaração sobre alguns pontos da ética sexual", de 1976; "Sobre o cuidado pastoral de pessoas homossexuais", de 1986; o "Catecismo católico"; de 1992.

Outro documento, mencionado por Luís Corrêa Lima (2017), diz respeito às orientações da Cúria Romana, publicado em 2007, sobre o uso da psicologia para admissão e formação de seminaristas, através de testes e psicoterapia, de modo circunstancial, a fim de buscar um equilíbrio entre as motivações espirituais, humanas e afetivas. A orientação é de que a formação seja interrompida, caso o candidato não seja capaz de “'enfrentar de modo realista' suas graves imaturidades'. Entre elas, são mencionadas: forte dependência afetiva, notável falta de liberdade nas relações, excessiva rigidez de caráter, falta de lealdade, identidade sexual incerta e tendências homossexuais fortemente enraizadas" (Luís Corrêa LIMA, 2017, p. 4). Dito isto, o autor observa que a homossexualidade não é, necessariamente, causa de impedimento para a ordenação sacerdotal, mesmo que categorizada como grave imaturidade, "mas a incapacidade de se lidar com ela de maneira adequada. E, seja quem for o candidato, ele não deve viver o celibato a qualquer preço, sacrificando o seu equilíbrio emocional" (Luís Corrêa LIMA, 2017, p. 4). Sendo assim, Luís Corrêa Lima (2017) propõe uma espécie de revisionismo sobre o modo como a Igreja tem recebido e tratado os candidatos homossexuais, ao sacerdócio:

Para o devido acompanhamento de candidatos homossexuais ao sacerdócio e à vida religiosa, é necessário que a instituição, seja ela diocese, paróquia ou instituto, verifique se está preparada para este 
tipo de vocacionado. São pessoas cuja afetividade e sexualidade extrapolam o convencional, exigindo um tratamento diferente e específico. É uma ofensa à dignidade do ser humano receber alguém em um ambiente onde as pessoas, especialmente as encarregadas do acompanhamento, não estejam abertas para isso. Não é justo nem evangélico introduzir alguém em um ambiente onde o veem como anormal, doente ou "coitadinho". Ninguém se sente bem sendo motivo de deboche, vendo pessoas cochichando pelos cantos, ou ouvindo piadas. Para receber um candidato homossexual é preciso criar um ambiente acolhedor, onde a diferença não seja vista como chaga, pecado ou algo semelhante (Luís Corrêa LIMA, 2017, p. 6).

Rogério Diniz Junqueira (2013), ao se referir à "pedagogia do armário", contribui para pensarmos como o currículo, as práticas de controle e policiamento colaboram para a gestão das fronteiras cisgêneras, (hetero)normativas e funcionam como um regime de vigilância, apagamento e silenciamento da sexualidade, que sustentam a LGBTfobia. Em suma, podemos afirmar que o seminário, como instância educativa, cumpre bem o seu papel na perpetuação daquilo que Rogério Diniz Junqueira nomina como "pedagogia do armário",

[...] constituída de dispositivos e práticas curriculares de controle, silenciamento, invisibilização, ocultação e não nomeação, que agem como forças heterorreguladoras de dominação simbólica, deslegitimação de corpos, saberes, práticas e identidades, subalternização, marginalização e exclusão (2013, p. 483).

Desse modo, ao olharmos para este conjunto de regras e normativas, estamos de acordo com Sílvio José Benelli (2006) que, em sua pesquisa de Mestrado intitulada "Pescadores de Homens: a produção da subjetividade no contexto institucional de um seminário católico", encara o seminário sob a concepção foucaultiana de poder, como um espaço de práticas disciplinares, uma agência de produção e modelagem da subjetividade que é exercido pelas estratégias microfísicas do poder, validado por meio de suas leis, normas, discursos, símbolos, gestos, dentre outros artifícios que colaboram para reforçar os valores hegemônicos e apagamentos daqueles cujos corpos não obedecem à ordem heteronormativa. 
Para Sílvio José Benelli (2006), o seminário é uma instituição que afirma os votos de celibato e de castidade aos seminaristas, utilizando de mecanismos aparentemente repressivos para controlar a sexualidade. Porém, ao proibi-la, o efeito que causa é o de incitá-la ainda mais. Assim, o seminário pode ser visto como uma máquina de produção de identidade nos seminaristas, para formar, modelar, disciplinar..., mas "isso não cola”, como afirma Sílvio José Benelli (2006, p. 171). 0 autor pontua que os seminaristas resistentes ao processo de modelagem são perspicazes, mostram que "a questão identitária é apenas um jogo. Eles jogam, mas não colam no modelo” (Sílvio José BENELLI, 2006, p. 171). Tal fato evidencia que na homogeneização do gênero e da sexualidade, o processo de docilização dos corpos sempre passa por torções e lapsos, pois: "[...] os corpos, assim, não se conformam diretamente às regras que os regulam, nunca aderindo completamente às normas que impõem as suas materializações" (Pedro Paulo Gomes PEREIRA, 2006, p. 471).

0 efeito de não falar ou silenciar-se sobre, geralmente acarreta no estabelecimento de relacionamentos ocultados, advindos de um intenso erotismo manifestado no flerte, na paquera, "na formação de casais apaixonados, em amores secretos, nem sempre discretos, platônicos ou intensamente carnais" (Sílvio José BENELLI, 2006, p. 168). Por outro lado, tornar-se padre pode aparecer como uma forma de escapatória, como é afirmado por Luís Correa Lima (2017), que explica que não é surpresa que rapazes homossexuais se sintam compelidos à vida religiosa, uma vez que a disciplina do celibato o protege da necessidade social de explicações sobre namoradas e/ou a cobrança sobre quando se casará com uma mulher. Semelhantemente ao autor supracitado, Frederic Martel também argumenta que:

Juntando-se ao clero, tudo se torna simples para o homossexual que não se assume: passa a viver entre rapazes e a usar túnicas; param de lhe perguntar sobre as namoradas os colegas de escola, que já faziam piadas de mau gosto, ficam impressionados; estão de acordo com as honras, ele que era alvo de escárnio: junta-se a uma raça eleita, ele que pertencia a uma raça maldita; e a mamãe, repito, que compreendeu tudo sem dizer nada, incentiva essa vocação miraculosa (2019, p. 24). 
Desta maneira, ainda que de maneira camuflada, entre os muros religiosos, em meio ao discurso da castidade e do celibato, "encontramos o frescor do desejo e uma sexualidade fervilhante" (Sílvio José BENELLI, 2006, p. 168) que, por vezes, é negada, punida, motivo de vergonha, subjugada e, por isso, geralmente é driblada por diversas táticas de repressão, como veremos de forma mais veemente na próxima seção. Durante a reportagem de Vitor Hugo Brandalise (2020), os entrevistados afirmaram que parte significativa dos candidatos ao sacerdócio são homossexuais: "Um seminarista disse à reportagem que, em sua turma de 40 estudantes no interior de São Paulo, 30 seriam homossexuais. E uma pesquisadora que estuda um monastério católico no Nordeste afirma que, lá, '90\% do clero é gay'” (Vitor Hugo BRANDALISE, 2020, s/p).

Durante esta mesma reportagem, um dos entrevistados afirmou que estava lendo o livro: "Batalha pela normalidade sexual e homossexualismo" (Gerard AARDWEG, 2000), escrito pelo psicólogo Gerard Aardweg ${ }^{6}$. Neste livro, o autor defende que a homossexualidade é uma anormalidade que vai contra a "natureza humana", assim, sugere que há a possibilidade de reversão da homossexualidade para a heterossexualidade por meio de uma autoterapia:

os homossexuais militantes procuram forçar o público a admitir a idéia de que são normais, exercendo o papel de vítimas de discriminação e apelando assim para os sentimentos de compaixão e justiça e para o instinto de proteção dos fracos, em vez de convencer por meio de argumentos e provas racionais. Isto mostra claramente que

6 Buscando pela biografia de Aardweg, de acordo com o site "Terça Livre" (s/a, s/p - grifo nosso), trata-se de: "um psicólogo natural dos Países Baixos, que se ocupa principalmente com a homossexualidade. Estudou psicologia na Universidade de Leiden e recebeu o título de PH. D. em psicologia na Universidade de Amsterdã. Trabalha como terapeuta há quase 50 anos em sua pátria, Holanda. Especializou-se em casos de homossexualismo (sic) e de problemas conjugais. Ministrou conferências no mundo todo, no Brasil inclusive Pontifícia Universidade Católica de Campinas (PUC-Campinas), escrevendo diversos livros sobre homossexualidade e pedofilia, assim como a relação destes temas com outros: a atração homoerótica no sacerdócio, a Humanae Vitae e os efeitos da paternidade homossexual. Van den Aardweg foi membro do Comitê Científico Assessor da Associação Nacional para a Pesquisa e Terapia da Homossexualidade, desde que a organização foi fundada em 1992. É também o editor europeu da revista Empirical Journal of Same-Sex Sexual Behavior". 
conhecem a fraqueza da lógica de sua posição. A veemente emotividade dos homossexuais é uma tentativa de compensação exagerada de sua falta de fundamentos racionais. Com pessoas desta estrutura mental, é quase impossível uma discussão verdadeira, pois elas recusam considerar qualquer opinião que não endosse plenamente seu dogma de normalidade. Mas será que no íntimo elas realmente acreditam nisso? (AARDWEG, 2000, p. 20).

As afirmações de Gerard Aardweg (2000), além de inscreverem a homossexualidade na categoria de "desvio", "anormalidade", "patologia", etc., contribuem para reafirmação da LGBTfobia e da ideia de que a sexualidade é um aspecto que possa ser "corrigido" ou "curado", ainda que a psicologia já tenha destacado que a heterossexualidade, homossexualidade, lesbianidade, bissexualidade... não são escolhas ou patologias. Consideramos tais afirmações profícuas para nosso estudo, pois explicitam o quanto as pautas que tangem a sexualidade - ainda que ocultadas e/ou repleta de tabus - não estão aquém da vida dos sacerdotes e candidatos à vida sacerdotal. Portanto, merecem e devem ser debatidas no cerne das pesquisas acadêmicas.

\section{2 "OS PADRES GAYS SILENCIADOS PELA IGREJA NO BRASIL": A REPORTAGEM DA BBC NEWS}

Na reportagem intitulada "Gelo no pênis, exorcismo e medo; os padres gays silenciados pela Igreja no Brasil”, realizada pelo jornalista Vitor Hugo Brandalise, divulgada em março de 2020, pela BBC News Brasil (British Broadcasting Corporation), entrevistou seis homens, padres e seminaristas, todos homossexuais, que aceitaram compartilhar suas histórias ${ }^{7}$. Como é descrito na reportagem:

Reforçamos que os dados que são apresentados, apesar de estarem articulados as temáticas que temos nos debruçado, não são os dados propriamente analisados em nossa pesquisa de doutoramento. Nossos dados empíricos, ainda estão em processo de coleta e análise, não sendo, portanto, plausível apresentá-los neste momento. Dito isto, colocamos em análise apenas algumas das discussões que partem dos relatos que dispomos através da reportagem de Vitor Hugo Brandalise (2020). Sendo assim, não descartamos a possibilidade de que outras vivências que difiram daquelas que são evidenciadas pelo jornalista. 
Seis padres e seminaristas homossexuais de cinco Estados brasileiros aceitaram compartilhar suas histórias, ao longo de um mês, com a reportagem da BBC News Brasil. Todos pediram anonimato, por receio de punições. Mesmo que vivam o celibato, como pede a doutrina católica, se os seus superiores considerarem que têm orientação sexual inadequada, eles podem ser expulsos da Igreja (Vitor Hugo BRANDALISE, 2020, s/p).

Durante a reportagem, são transcritos e expostos vários relatos dados pelos entrevistados, sendo que um destes concordou em gravar entrevista, uma vez que não tivesse seu rosto exposto e sua voz fosse alterada. Como forma de organizar e identificar os participantes, elaboramos o quadro a seguir. Por questões éticas e de sigilo, todos os nomes foram alterados pela reportagem, entretanto dois deles não foram identificados, assim tomamos a liberdade por descrevê-los como: Entrevistado 5; Entrevistado 6.

\begin{tabular}{|l|l|}
\hline ENTREVISTADO & IDADE \\
\hline Rafael & 45 anos \\
\hline Aurélio & 36 anos \\
\hline Alexandre & 43 anos \\
\hline André & Não identificado \\
\hline Entrevistado 5 & Não identificado \\
\hline Entrevistado 6 & Não identificado \\
\hline
\end{tabular}

Fonte: Elaborado pelos/as autores/as, a partir dos dados da entrevista de Vitor Hugo BRANDALISE (2020)

Tendo em vista o objetivo desta pesquisa e como forma de estruturar este estudo, organizamos o tópico a seguir, em que expomos alguns dos excertos da reportagem com os relatos dos participantes e as análises subsequentes.

2.1 "O único pecado era a sexualidade": culpa, (auto) punição e confissão Para começar esta análise, destacamos as maneiras de controle e punição dos desejos sexuais, de forma mais específica, os relacionados à masturbação. Neste primeiro excerto da reportagem, é apresentado 
o caso de Rafael, que relatou as diversas estratégias para "eliminar" a homossexualidade. Para isto, rezava freneticamente, agredia o pênis, envolvia o genital com cubos de gelo, pedindo para que o "espírito maligno" o abandonasse. Vejamos:

\section{Trecho 1}

No meio da noite, num seminário católico em São Paulo, um aspirante a padre se martirizava: "Em nome de Jesus, demônio da homossexualidade, saia de mim!". Deitado em sua cama no quarto que dividia com dois religiosos, Rafael, de 20 anos, apertava as unhas nas palmas das mãos até quase machucar, e rezava sem parar. Insone, caminhava até o banheiro e, esbravejando e chorando, agredia o seu órgão sexual e o envolvia em cubos de gelo. Deitava no chão gelado ou, em outros momentos, ficava sob a ducha fria até amanhecer, rezando e suplicando. "Espírito inimigo, manifestação do Mal. Saia de mim!" (Vitor Hugo BRANDALISE, 2020, s/p).

Sobre o trecho supracitado, destacamos vários pontos passíveis de discussão. Em primeiro lugar, observamos como o fato do seminarista vigiar-se e punir-se constantemente, evidencia o quanto a noção de pecado está ligada ao próprio corpo em si, "assim, tudo que está no corpo, ou passa pelo corpo, ou melhor, pelo seu desejo e prazer deve ser encarado desde o início de sua conscientização, falando do desejo e prazer carnal" (Nathan Melo da COSTA, 2017, p. 67). Desta maneira, o mero fato de pensar, sentir o desejo sexual, ponderar a possibilidade de tocar-se, já são motores suficientes para penalizações, castigos e repreensões sobre si mesmo. Neste entendimento, a masturbação é a primeira forma de punição, já que é um desejo que atravessa o corpo e os desejos internos ao sujeito (Nathan Melo da COSTA, 2017), como é destacado por Michel Foucault (2001, p. 243),

O discurso da revelação, o discurso da vergonha, de controle, de correção da sexualidade, começa essencialmente na masturbação. Mais concretamente ainda, esse imenso aparelho técnico da penitência quase só teve efeito, é verdade, nos seminários e nos colégios, isto é, nesses lugares em que a única forma de sexualidade a controlar era, evidentemente, a masturbação. 
Na perspectiva de Michel Foucault (2001), a campanha "antimasturbação" se corroborou a partir da noção de que ela se insere numa região intermediária entre o discurso cristão e o discurso da psicopatologia sexual. Foi uma "empreitada que fez uso do anúncio de risco da patologização e somatização do sujeito que se masturbava” (Nathan Melo da COSTA, 2017, p. 75). Foi assim que foram cunhadas três associações possíveis entre masturbação e patologia: a primeira, como uma doença que reuniria todas as doenças possíveis; a segunda, como a base possível de todas as doenças; a terceira, como uma estratégia médica que procurava convencer os/as jovens de que suas doenças estariam relacionadas à masturbação. Destarte, "a masturbação está se tornando a causa, a causalidade universal de todas as doenças" (Michel FOUCAULT, 2010, p. 210). Levando em conta este olhar patologizante, é compreensível que o policiamento da homossexualidade, somada ao proibicionismo da masturbação, reforçam os discursos de penalização da sexualidade, apresentados pela reportagem, como: "Em nome de Jesus, demônio da homossexualidade, saia de mim!" (Vitor Hugo BRANDALISE, 2020, p. s/p) ou "Meu Deus, estou desconfiado de que sou gay. Nem mereço estar vivo" (Vitor Hugo BRANDALISE, 2020, p. s/p). Tal fato acarreta na preocupação e no policiamento constante dos gestos, comportamentos e atitudes, como é exposto nos fragmentos a seguir:

\section{Trecho 2}

"Será que eu tenho algum trejeito, será que estou andando direitinho, estou pregando com muitos gestos? A minha voz é afeminada? Já passei por isso e colegas me perguntam o mesmo. Você fica o tempo todo preocupado, atrapalhado", disse (Vitor Hugo BRANDALISE, 2020, s/p).

\section{Trecho 3}

"Uns anos atrás, cinco foram convidados a sair. Eu fui um deles. Perseguir os que consideram mais afeminados, além de injusto, favorece o fingimento, as pessoas enrustidas e homofóbicas. Esse seminarista, hoje aos 29 anos, não se esquece de como a homossexualidade era tratada pelo seu formador no seminário do qual foi expulso, no Piauí. "Ele dizia que 'homossexual tende sempre a olhar para a virilha dos outros homens e, por isso, não se concentram e trabalham mal'. Nas semanas seguintes, eu olhava para o teto, via uma viga de madeira, 
me enxergava pendurado nela pelo pescoço. Mexeu muito comigo" (Vitor Hugo BRANDALISE, 2020, s/p).

O (auto) policiamento pode ser percebido nos trechos acima, por meio do controle dos gestos, da voz, dos "trejeitos" e até mesmo do olhar, "levando ao extremo, que tudo possa servir para punir a mínima coisa [...]" (Michel FOUCAULT, 1987, p. 202). Tal fato pode ser relacionado ao conceito de panóptico que favorece a punição e a submissão. Michel Foucault (1985) utiliza da ideia de panóptico, idealizado pelo jurista inglês Jeremy Bentham, para designar o sistema de vigilância ideal para uma penitenciária. Configura-se da seguinte forma:

[...] na periferia, uma construção em anel; no centro, uma torre; esta possui grandes janelas que se abrem para a parte interior do anel. A construção periférica é dividida em celas, cada uma ocupando toda a largura da construção. Estas celas têm duas janelas: uma abrindo-se para o interior, correspondendo às janelas da torre; outra, dando para o exterior, permite que a luz atravesse a cela de um lado a outro. Basta então colocar um vigia na torre central e em cada cela trancafiar um louco, um doente, um condenado, um operário ou um estudante (Michel FOUCAULT, 1985, p. 182).

Consideramos profícuo o conceito de panóptico para esta discussão, já que faz uma metáfora com os mecanismos que favorecem o controle, vigilância e punição dos corpos, ao mesmo tempo em que docilizam e moldam a subjetividade por meio de sua ação sobre a "[...] maneira de ser (grosseria, desobediência), dos discursos (tagarelice, insolência), do corpo (atitudes "incorretas", gestos não conformes, sujeira), da sexualidade (imodéstia, indecência)" (Michel FOUCAULT, 1987, p. 202). 0 dispositivo panóptico ainda pode ser observado, durante a reportagem, no ponto em que os entrevistados abordaram as regras de convívio dos seminaristas, a inibição de amizades próximas, a fim de impedir a formação de casais entre os rapazes:

Trecho 4

"Andar em duplas pelos corredores e pátios à noite, por exemplo, era visto com maus olhos. Os dormitórios eram compartilhados, 
sempre, entre três ou cinco seminaristas. "Nunca duas, nunca quatro pessoas. Era uma regra que todos entendiam: para evitar a formação de casais", conta o padre. "Mas o que acabava inibindo eram as amizades". Assistir ao telejornal depois do jantar, ou ir ao cinema, só se os seminaristas estivessem em números ímpares. "Provoca um clima tenso, não é natural, tranquilo. Sempre há olhos em você. E isso se prolonga por sete, oito anos", diz um outro seminarista" (Vitor Hugo BRANDALISE, 2020, s/p).

Deste modo, o panóptico aqui se expressa no controle e vigilância sobre os internos, reverbera no estabelecimento de um clima persecutório, que faz com que se cumpram as obrigatoriedades institucionais, "ao mesmo tempo, salienta a infração de um indivíduo no contexto global da obediência visível e constantemente examinada dos demais" (Sílvio José BENELLI, 2006, p. 156). Entretanto, não podemos simplificar a ideia do panóptico como um mecanismo de poder que atue a todo o momento de forma explícita, dizendo não e reprimindo o sujeito. Muito pelo contrário, o que faz com que ele funcione é justamente o fato de que "não pesa só como uma força que diz não, mas que de fato ele permeia, produz coisas, induz ao prazer, forma saber, produz discurso" (Michel FOUCAULT, 1985, p. 10). Ou seja, o panóptico já não é apenas um mecanismo externo, pois ele está incluso no próprio sujeito, como uma espécie de "sentimento de estar sempre olhando para si mesmo através dos olhos dos outros e medindo a própria alma com a fita métrica do mundo que o encara atemorizado, com desprezo ou piedade" (Bruno GUANDALINI; Guilherme TOMIZAWA, 2013, p. 29).

Neste sentido, é possível compreender os relatos, que expõem o quanto os seminaristas e padres se sentiam constantemente vigiados e a necessidade de se remodelarem aos acordos e normas pré-estabelecidas institucionalmente. Bruno Guandalini e Guilherme Tomizawa (2013, p. 31) apontam que se trata de: "registrar e reconhecer o 'anormal' para filtrá-los da sociedade dos 'normais'”. Normatividade que, no caso, busca "[...] convencer a sociedade de que a única prática sexual aceitável era e continua sendo a cis heterossexual" (Megg Rayara Gomes de OLIVEIRA, 2018, p. 165). Dentre as várias estratégias reveladas pela reportagem da BBC, figura a tentativa de privação de necessidades humanas básicas 
e a confissão como um alívio possível ao "pecado", conforme relatos de Aurélio e de Rafael:

\section{Trecho 5}

"Aos 20 anos, Aurélio acreditou que a privação do sono seria uma boa forma de frear seus desejos (fortes naquele tempo, segundo ele conta). "Me obrigava a dormir três horas por noite, no máximo. Fazia trabalhos de graça, virava noites, me cansava muito. Achava que, se eu estivesse bem desgastado, não teria desejos", contou o padre. Como resultado, perdeu mais de 10 quilos e, numa manhã, caiu de cama e durante dias não pôde se levantar. Um alívio possível, nesse contexto, era a confissão. "Eu chegava a ir de roupão ao confessionário. Saía do banho morrendo de culpa por ter tido prazer sexual sozinho", relembra o padre Rafael. "Era um alívio incompleto. Não sentia confiança no padre confessor, não falava das minhas fantasias com receio de ser perseguido. Logo depois me sentia culpado de novo. A sexualidade era esse inferno, de dia e de noite. Um terror" (Vitor Hugo BRANDALISE, 2020, s/p).

No trecho destacado, temos a presença da confissão como uma espécie de conforto/alívio ao sentimento de culpa pelo prazer sexual. Isso remete à ideia trabalhada por Michel Foucault (1985; 2010), na qual o autor afirma que a confissão é desde os primórdios da Igreja Católica, um dos principais dispositivos de controle para interditar o uso do corpo e dos prazeres sexuais. Uma vez considerada pecaminosa toda e qualquer prática sexual fora do matrimônio sacramentado, toda atividade que infrinja esta regra, deve ser submetida à confissão, que pode ser compreendida como um ritual de sujeição, um discurso de culpa, que produz "modos de ser e falar definidos e desejáveis, corroborando poder a quem diagnostica tais modos de ser" (Nathan Melo da COSTA, 2017, p. 54) ou como afirma Michel Foucault (1987, p. 56) "a confissão torna a coisa notória e manifesta".

Outro ponto presente no Trecho 5, é o momento em que o entrevistado relata que "não sentia confiança no padre confessor, não falava das minhas fantasias com receio de ser perseguido" (Vitor Hugo BRANDALISE, 2020, s/p). O fato de o seminarista limitar sua fala, não explanar seus desejos, o medo de alguma retaliação, evidencia os pontos limítrofes impostos na produção do discurso ou as interdições à 
palavra, o que para Michel Foucault (2014) se afirma como princípio de exclusão nos discursos políticos e, principalmente, da sexualidade, lugar em que o poder se exerce de modo mais privilegiado. Para além da interdição, o autor aponta ainda o funcionamento de outro princípio de exclusão: separação e rejeição. Esta noção se dá em vista das concepções históricas de razão e loucura, haja vista que a palavra dos ditos "loucos" e "anormais", "não eram nunca recolhidas nem escutadas" (Michel FOUCAULT, 2014, p. 11). Nas palavras do autor,

Desde a alta Idade Média, o louco é aquele cujo discurso não pode circular como os dos outros: pode ocorrer que sua palavra seja considerada nula e não seja acolhida, não tendo verdade nem importância, não podendo testemunhar na justiça, não podendo autenticar um ato ou um contrato, não podendo nem mesmo, no sacrifício da missa, permitir a transubstanciação e fazer do pão um corpo [...] (Michel FOUCAULT, 2014, p. 10).

Partindo da compreensão foucaultiana de que a produção de um discurso envolve o acolhimento dos pressupostos que são tomados como válidos e que viabilizam as ditas "verdades" (Michel FOUCAULT, 1985), logo, aqueles discursos que, de alguma maneira, escapam às ideias (cishetero) normativas sobre o sexo, o gênero e a sexualidade, são passíveis de sanções e exclusões. Estabelecemos uma relação intrínseca com os relatos dos entrevistados a respeito dos silenciamentos, das expulsões e retaliações que alegaram sofrer, uma vez que na posição de religiosos e homossexuais, lutavam para se enquadrar nas "verdades" que a eles era infligida. Deste modo, dentre as formas de escape e de resistência que percebemos nos relatos expostos na reportagem, figuram táticas desenvolvidas pelos padres e seminaristas para driblar tais interdições:

\footnotetext{
Trecho 6

"Para um outro seminarista, de Minas Gerais, que teve uma experiência positiva ao revelar de cara sua orientação ao superior, a preocupação é "com a fachada". "A reação do meu orientador foi marcar uma conversa com um bispo, no dia seguinte. Fui até lá, o bispo me ouviu, agradeceu a franqueza e me disse pra seguir em frente", contou o estudante, de 27 anos. "E falou que meu orientador
} 
me ensinaria 'como agir'. Entendi que só não podia ter escândalo. A ideia é dissimular, para não perder a fé das senhorinhas devotas" (Vitor Hugo BRANDALISE, 2020, s/p).

Palavras como: driblar, dissimular, disfarçar, são expressões que se inserem no cotidiano do seminário, como foi identificado na pesquisa desenvolvida por Sílvio José Benelli (2006). Ao observar o cotidiano dos seminaristas o autor notou que, apesar dos enunciados em documentos sacerdotais que se utilizam de expressões como "plasmar", "formar", "modelar", "inculcar" uma identidade sacerdotal, há uma diversidade de situações/brechas (festas, momentos de confraternização, etc.) que evidenciaram como existem torções, lapsos, que há um jogo de "esconde-esconde", que fazem com que a estratégia disciplinar se torne "mais difusa, invisível e capilar" (Sílvio José BENELLI, 2006, p. 178). Ou, como é salientado por Frederic Martel, as aparências que se sobrepõem aos votos de fé sobre os votos de celibato e castidade, podem esconder "uma realidade totalmente diferente" (2019, p. 11). Todavia, Luiz Corrêa Lima alerta para a necessidade de cautela para que não incorramos no erro, tanto de movimentos ultraconservadores do catolicismo, quanto de movimentos libertários, que afirmam que "para a Igreja, gay não pode ser padre'” $(2008$, p. 2). Nem todos os sacerdotes ou candidatos ao sacerdócio homossexuais vivem em condição de sofrimento. Há uma parcela daqueles que vivem em harmonia com a sua sexualidade e com o contexto religioso. Para tanto, o autor coaduna com a perspectiva de um cristianismo inclusivo, em que o sacerdócio celibatário, seja ele: gay, hétero, bissexual... possa ser vivido de forma honesta, sem discriminações, mas, para tanto, de antemão "deve-se reconhecer e respeitar a mais ampla e legítima diversidade no campo da sexualidade" (Luiz Corrêa LIMA, 2008, p. 2).

\section{CONSIDERAÇÕES FINAIS}

A partir desta pesquisa percebemos que, apesar de alguns avanços no que tange à discussão da homossexualidade no âmbito do seminário católico, o tema ainda é permeado por tabus, uma vez que existem documentos que tratam explicitamente da homossexualidade e que 
afirmam que as pessoas que apresentem as supostas "tendências homossexuais" são orientadas a não serem admitidas às ordens sacras, e ainda que, caso decidam prosseguir no seminário, devem enfrentar um processo de provação constante.

Uma das críticas de Edênio Valle é a de que os documentos de "discernimento vocacional" ignoram as relações, "dependências e transferências grupais que se dão dentro de um seminário e dentro de um grupo de formandos em sua relação com os responsáveis pela formação" (2014, p. 20).

Neste ponto, rememoramos que os relatos dos entrevistados pela BBC News indicam que as relações que permeiam a vida do candidato ao sacerdócio influem e causam movimentos sobre a sexualidade. Além disso, as falas dos entrevistados da reportagem evidenciam que o processo de constituição da sexualidade do seminarista é permeado por micropoderes (Michel FOUCAULT; 1985; 1987; 1988; 2001; 2014) que se expressam nas contenções, confissões, silenciamentos e proibições, que são reverberadas em sofrimento, repressões e (auto) punições. No entanto, como foi ilustrado através dos relatos da reportagem da BBC, em consonância com pesquisas recentes (Nathan COSTA, 2017; Frederic MARTEL, 2019), há a percepção mais atual de que ser homossexual e fazer parte do clero é possível (por baixo dos panos), porém exige uma série de dribles. Nisto, "a palavra e a visibilidade são proibidas" (Frederic MARTEL, 2019, p. 21). Tais questões nos indicam a urgência de problematizarmos as temáticas de gênero e homossexualidade na vida dos sacerdotes e candidatos ao sacerdócio, uma vez que, apesar das leis clericais vigentes, tais marcadores estão imbricados com suas vivências, experiências e trajetórias.

\section{REFERÊNCIAS BIBLIOGRÁFICAS}

AARDWEG, Gerard. A batalha pela normalidade sexual e homossexualismo. Aparecida, SP: Editora Santuário, 2000.

ARQUIDICIOSE DE CAMPINAS. Fichas de estudo sobre o Vaticano II: Ficha 1 - História: O QUE É UM CONCÍLIO? 2017, s/p. Disponível em: <http://arquidiocesecampinas.com/ wp-content/uploads/2017/12/Ficha-1-O-que-\%C3\%Ag-um-concilio-Historia.pdf $>$. Acesso em 10 de out. 2020. 
BALISCEI, João Paulo. Abordagem histórica e artística do uso das cores azul e rosa como pedagogias de gênero e sexualidade. Revista Teias, Rio de Janeiro, v.21, ed. especial, p. 223-244, ago. 2020.

BENELLI, Sílvio José. O seminário católico e a formação sacerdotal: um estudo psicossocial. Psicologia USP, v.17, n. 3, p. 145-182, set. 2006.

BRAGA, Claudomilson Fernandes. Celibato e gênero: uma releitura crítica. 126f. Dissertação (Mestrado em Ciências da Religião) - Universidade Católica de Goiás - Goiânia, 2007. BRANDALISE, Vitor Hugo. Gelo no pênis, exorcismo e medo; os padres gays silenciados pela Igreja no Brasil. BBC News Brasil. 9 março 2020. Disponível em: <https://www.bbc. com/portuguese/brasil-51554441>. Acesso em 18 de set. 2020.

CARVALHO JÚNIOR, Macário Lopes de. Gentios, judeus e hereges: os não cristãos nos concílios de Elvira (306) e Arles (314). Romanitas - Revista de Estudos Grecolatinos, n. 1, p. 54-70, 2013.

CARVALHO JÚNIOR, Macário Lopes de. Os concílios de Elvira e Arles na configuração do Cristianismo Tardo-Antigo. 20of. Dissertação de Mestrado - Programa de Pós-graduação em História - Universidade Federal do Amazonas - Manaus, 2010.

COSTA, Nathan Melo. Religião e Sexualidade: um estudo da vida celibatária dos seminaristas no Rio de Janeiro. 127f. Dissertação de Mestrado - Programa de Pós-Graduação em Psicossociologia de Comunidades e Ecologia Social - Instituto de Psicologia, Universidade Federal do Rio de Janeiro - Rio de Janeiro, 2017.

CONGREGAÇÃO PARA A EDUCAÇÃO CATÓLICA. Instrução sobre os Critérios de Discernimento Vocacional acerca das Pessoas com Tendências Homossexuais e da sua Admissão ao Seminário e às Ordens Sacras. Roma, 4 nov. 2005. Disponível em: <http:// www.vatican.va/roman_curia/congregations/ccatheduc/documents/rc_con_ccatheduc_doc_20051104_istruzione_po.html>. Acesso em 26 de set. 2020.

DABHOIWALA, Faramerz. As origens do sexo: uma história da primeira revolução sexual. 1.ed. São Paulo: Globo, 2013.

DAIBERT JR, Robert. Entre homens e anjos: padres e celibato no período colonial do Brasil. In: DEL PRIORI, Mary; AMANTINO, Márcia (Orgs.). História dos homens no Brasil. São Paulo: Editora Unesp, 2013, p. 49-84.

ENDSJO, Dag Oistein. Sexo e religião: do baile de virgens ao sexo sagrado homossexual. São Paulo: Geração Editorial, 2014.

FIGUEIRÓ, Mary Neide Damico. Formação de educadores sexuais: adiar não é mais possível. 2 ed. Londrina/PR: Eduel, 2014.

FOUCAULT, Michel. História da sexualidade I: a vontade de saber. Rio de Janeiro: Edições Graal, 1988.

FOUCAULT, Michel. Os anormais: curso no College de France (1974-1975). São Paulo: Martins Fontes, 2001. 
FOUCAULT, Michel. A ordem do discurso: a aula inaugural no Collége de France, pronunciada em 2 de dezembro de 1970. São Paulo: Edições Loyola, 2014.

FOUCAULT, Michel. Microfísica do poder. Rio de Janeiro: Graal, 1985.

FOUCAULT, Michel. Vigiar e punir: nascimento da prisão. Petrópolis/RJ: Vozes, 1987.

FRANÇA, Fabiane Freire. Representações Sociais de gênero na escola: diálogo com educadoras. 2014. 186 f. Tese (Doutorado em Educação) - Universidade Estadual de Maringá, Maringá, PR, 2014.

GUANDALINI, Bruno; TOMIZAWA, Guilherme. Mecanismo Disciplinar de Foucault e o Panóptico de Nentham na Era da Informação. ANIMA: Revista Eletrônica do Curso de Direito das Faculdades OPET. Curitiba, PR - Brasil, v.4, n.9, p. 23-41, jan/jun. 2013.

JUNQUEIRA, Rogério Diniz Junqueira. Pedagogia do armário: A normatividade em ação.

Revista Retratos da Escola, Brasília, v. 7, n. 13, p. 481-498, jul./dez. 2013.

LIMA, Luís Corrêa. Candidatos com Orientação Homossexual ao Sacerdócio e à Vida Religiosa Consagrada. Revista Convergência, ano. LII, p. 1-9, dez. 2017.

LIMA, Luís Corrêa. Gays, Psicologia e Sacerdócio. 2008. Disponível em: <http://www. diversidadesexual.com.br/wp-content/uploads/artiguetes-professor/Gays,\%2opsicologia\%20e\%20sacerd\%C3\%B3cio.pdf>. Acesso em 30 de abr. 2021.

LOURO, Guacira Lopes. Gênero e sexualidade: pedagogias contemporâneas. Pro-Posições, Campinas/SP, 2008, v.19, n.2, p. 17-23.

MATOS, Marcos Paulo Santa Rosa. Discurso religioso e heteronormatividade: uma análise da liturgia nupcial da Igreja Católica. Porto Alegre: Fi, 2020.

MARTEL, Frédéric. No armário do Vaticano: poder, hipocrisia e homossexualidade. Rio de Janeiro: Objetiva, 2019.

MOTT, Luiz. Igreja e homossexualidade no Brasil: cronologia temática, 1547-2006. Comunicação apresentada no II Congresso Internacional sobre Epistemologia, Sexualidade e Violência, São Leopoldo, RS, Escola Superior de Teologia, 16/8/2006.

MUSSKOPF, André Sidnei. Via(da)gens teológicas: itinerários para uma teologia queer no Brasil. 525f. Tese (Doutorado em Teologia). Instituto Ecumênico de Pós-Graduação em Teologia. Faculdades EST, São Leopoldo, 2008.

NETO, Arlindo José de Souza. “O bem maior que posso ter": uma análise antropológica sobre a vocação sacerdotal católica no Brasil. Dissertação (Mestrado em Antropologia). 150 f. - Universidade Federal de Pernambuco, CFCH. Programa de Pós-Graduação em Antropologia, Recife, 2015.

OLIVEIRA, Megg Rayara Gomes. Trejeitos e trajetos de gayzinhos afeminados, viadinhos e bichinhas pretas na educação! Periódicus. n. 9, v. 1 maio-out. 2018, p. 161-191.

PEREIRA, Pedro Paulo Gomes. A teoria queer e a reinvenção do corpo. Cadernos Pagu, Campinas/SP, n. 27, p.469-477. jul/dez. 2006. 
SOUZA, Alessandra dos Reis. “A boa nova também é para mim”: novos sentidos sobre as homossexualidades no Projeto Aprisco. 136f. Dissertação. Programa de Pós-Graduação Interdisciplinar Sociedade e Desenvolvimento. Universidade Estadual do Paraná, Câmpus de Campo Mourão. Campo Mourão, 2020.

TERÇA LIVRE. Biografia Gerard Aardweg. s/a. Disponível em: <https://livraria.tercalivre. com.br/index.php?route=product/author\&author_id=754>. Acesso em: 26 de jan. 2021. VALLE, Edênio. Orientações recentes da Santa Sé sobre a homossexualidade nos seminários católicos. In: VALLE, Edênio (Org.). Tendências homossexuais em seminaristas e religiosos. 2. ed. São Paulo: Edições Loyola Jesuítas. 2014. p. 15-24.

XAVIER, Antônio Roberto; CHAGAS, Eduardo Ferreira; REIS; Edilberto Cavalcante. Cultura e educação na Idade Média: aspectos histórico-filosófico-teológicos. Revista Dialectus, Ceará, v.4, n. 11, p. 310 - 326. ago/dez. 2017.

Submetido em: 2-11-2020

Aceito em: 19-5-2021 